\title{
RURAL RELIEF IN THE SOUTH: FERA'S PROBLEM IN EASTERN NORTH CAROLINA
}

\author{
Gordon W. BLACKWRLL*
}

One may look back to the time not so long ago when social work was linked almost inseparably in the mind of the general public with caring for the indigent and disabled population of urban centers. Little more than a decade and a half ago several states including North Carolina pioneered in the field of state-wide public welfare organization based on the county-unit plan. Thus welfare services were made available to rural communities. This marked a turning point in the evolution of public welfare work, which was gradually becoming a recognized and necessary function of government, Out of the depression has come the Federal Emergency Relief Administration (FERA) and an American attitude toward welfare activities which was foreshadowed by early advocates of welfare work in rural communities. It is now recognized that economic distress is not confined to large cities and furthermore that millions of normal human beings are in need through no fault of their own.

True, the aged, widowed, and disabled are still with us, but it is significant that at present they constitute only a minor portion of the relief load. In many states old age pensions, mothers' aid, hospitalization, vocational rehabilitation and the like are caring for some in these groups. Direct relief from federal funds is bearing most of this burden. But at least two-thirds of the nation's relief cases appear to be normal families capable of becoming self-supporting if given a fair opportunity, together with scientific, constructive case work.

What is more significant from the point of view of this paper is the fact that the old idea that welfare work in rural districts is unnecessary-"no one can starve in the country"-has been dissipated. The past few years of declining prices for agricultural commodities have served to create rural areas of social waste as vicious to social well-being as the much publicised urban slums. This has been especially true of the rural South where the share-crop tenant system has been firmly entrenched in many localities. From 1929 to 1933 government efforts to help the farmer were conspicuous chiefly due to their failure. So it is that federal relief funds have

- A.B., I932, Furman University; M.A., 1933, University of North Carolina. Research assistant of The Southern Regional Study sponsored by the Social Science Research Council, I933; at present, research assistant of the Institute for Research in Social Science at the University of North Carolina on leave directing research surveys for the North Carolina Emergency Relief Administration. 
been called upon to aid several million farm families in the past year and a half. Their distribution has been vested in FERA.

A look at the situation in Eastern North Carolina may give some idea of the general conditions in the rural South. Aged, widowed, and physically or mentally disabled make up 25 to 35 per cent of the relief load in rural communities. These of course are charity cases and must be aided by direct relief grants. They will probably continue to be public charges in the future. The remaining 65 to 75 per cent, however, are capable of being self-supporting if a place for them can be found or created in the agricultural cconomy of the region.

In the case of those who own enough land on which they can be self-sustainingand many relief cases fall within this classification-the problem is one of obtaining credit until a return to normalcy enables them to get back on their feet financially. In the case of the rural home owner, with perhaps only a house and a few acres of cleared land, something more than credit is necessary. Additional acreage would enable him to be self-sustaining as a farmer, but with controlled crop production in prospect for several years this may not be possible. Another alternative is parttime work in an industry. In sparsely settled districts this is impractical. Tenants constitute a large part of Eastern Carolina's relief load. Starvation prices for farm products added to the evils inherent in the tenant system have resulted in distressing conditions for this group of farm families. In the most hopeless situation of all is the displaced tenant who is unable to get a crop for this year. Depression has set many tenants adrift. Acreage reduction has a tendency to contract the tenant system still further, making fewer share-crops available in spite of provisions in the contracts designed to protect the interests of the tenant. At the bottom of the agricultural scale is the day laborer who has never had owner or tenant status. A very large percentage of this group are not capable of managing a crop of their own. The demand for daily farm labor will decrease as acreage is reduced. As noted above, industries to take care of surplus farm labor on a large scale cannot flourish in most parts of the region.

So we have a general idea of the make-up of the rural relief load in Eastern North Carolina: first, the direct relief cases; second, a group of small farm owners; third, a group of rural home owners with several acres of land; and fourth, a group of families who own no real property, comprising tenants, displaced tenants, or day laborers. And now for a more detailed scrutiny of these groups as to their make-up and the nature of their problems.

\section{Types and Problems of Farmer Families On Relief ${ }^{1}$}

Small Farm Owners on Relief. The highest percentage of farm owners on relief rolls is found in the coastal trucking counties. Here small land owners are numerous

\footnotetext{
" The following discussion is based on data secured by a survey of active relief cases in Tyrrell County in eastern North Carolina, carried on in May, 1934, by a research group of the North Carolina Emergency Relief Administration; and also surveys of displaced tenant farm families on relief in Greene, Nash, and
} 
and the tenancy rate is low. In May, 1934, 49, or 13 per cent, of the active relief cases in Tyrrell County-typical of this coastal trucking region-were owners with enough land on which to be self-sustaining as farmers. Thirty-one of the cases are white, while I8 are colored. From the point of view of health, available labor in the family, and farming experience, all of these families seem capable of being self-supporting. Their present economic condition is indicative of their need for government aid.

Over an average farming experience of eighteen years, all of these farmers have raised food and feed crops yearly, more than two-thirds raising enough or almost enough to care for home consumption needs. These farmer families have not been slaves to a single money crop, only one-fourth reporting that they usually devote most of their acreage to products raised for market. Further inland in the center of the cotton and tobacco region, the record of small farm owners on relief doubtless would be less favorable from this point of view. An overwhelming majority of these Tyrrell County families are experienced in raising for home use the truck and garden products typical of the region. Every family is experienced in raising pigs and chickens, while a great majority are experienced in caring for a cow.

Not all of these farmers own as much cleared acreage as they desire to cultivate, more than one-half procuring additional land on shares or for cash rent. Two-thirds of the families depend on cash wages from day labor in farming, construction work, fishing, or lumbering to supplement income from their own farming operations.

Wilson counties, North Carolina, made in the winter and spring of 1934 by the same research group under the Tennessee Valley Authority in coöperation with the Institute for Research in Social Science and the North Carolina Emergency Relief Administration. Invaluable assistance in setting up the framework and directing the course of these surveys was sendered by Roy M. Brown of the North Carolina Emergency Relief Admipistration and by T. J. Woofter, Jr., and Harriet L. Herring of the Institute fon Research in Social Science. Following are census data" for Tyrrell County in 1930:

Total population ............... $5,16_{4}$

Urban.$\ldots \ldots \ldots \ldots \ldots \ldots \ldots \ldots \ldots \ldots$

Rural $\ldots \ldots \ldots \ldots \ldots \ldots \ldots \ldots \ldots \ldots, 5,16_{4}$

Rural farm .............. 3,152

Rural non-farm ........... 2,012

Average value per farm ...........\$4,300

Avcrage amount of mortgage per farm... \$1,599

Ratio of debt to value. ............. 37.2\%

Proportion farms mortgaged..........27.7\%

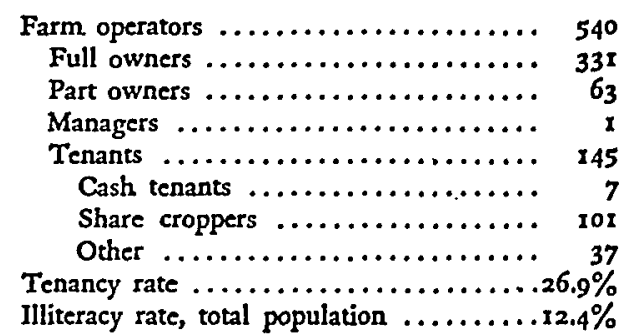

A classification of active relief cases in Tyrrell County in May, 1934, is set forth below:

Type Colored White Total PerCent

Direct Relief Cases................. 76

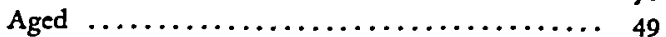

Widowed $\ldots \ldots \ldots \ldots \ldots \ldots \ldots \ldots \ldots \ldots \ldots$ 2I

Physically or mentally disabled.......... 6

Non-Farmer EMployable ReLief Cases........ 7

Rural Rehabilitation Relief Cases........... 89

Small farm owners ................. I8

Rural home owners ............... 2 II

Tenants, displaced tenants, and day laborers.... 50

Total Active Relief Cases.............. 172

\begin{tabular}{ccc} 
White & Total & Per Cent \\
63 & 139 & $37 \%$ \\
36 & 85 & 23 \\
13 & 34 & 9 \\
14 & 20 & 5 \\
6 & 13 & 3 \\
135 & 224 & 60 \\
31 & 49 & 13 \\
19 & 40 & 11 \\
85 & 135 & 36 \\
\hline 204 & -376 & 100
\end{tabular}


The average value of the farms owned by these families is $\$ \mathrm{r}, 35 \mathrm{I}$. Three-fourths of the farms are mortgaged, the average amount of the mortgage being \$1062. Onefourth are mortgaged for as much or more than the place is now worth. A majority of the mortgagees report favorably on the family involved and state that under normal conditions the mortgage should be paid off in time.

The typical farm owner on relief subsisted last year on a cash income of \$162, supplemented by relief to the amount of $\$ 54$. This represents a per capita total yearly income of approximately $\$ 44$. The rather low average income figure is due in part to the storm which struck the North Carolina coast in September, 1933. Almost all the crops, just ready for harvesting, were totally destroyed. Yet the storm was not the chief reason why these farm owners were forced to ask for help, as more than one-fourth of the present active cases were relief clients before that date. The present possessions of these families are not at all discouraging and emphasize the fact that what is needed is credit to tide the families over until agricultural recovery becomes an actuality. The average amount of debts, exclusive of mortgages, owed by these families is $\$ 24 \mathrm{x}$.

Reports from landlords for whom these families have tended crops were obtained if possible. Also case workers, work project foremen, and CWA foremen-individuals who have come in contact with these families often during the past eighteen months-were interviewed with the result that a well balanced group of opinions was obtained for every case. More than go per cent of the reports from each of these four sources were rated as favorable or medium.

The general conclusion that one reaches in regard to this group of small farm owners on relief is that most of the families are worthy and are capable of being self-supporting. They possess adequately furnished homes and enough land, livestock, and farming equipment to enable them to practice subsistence farming plus the raising of some money crop. What appears to be necessary is, first, government loans to prevent mortgage foreclosures; and second, enough capital for carrying on farming operations for perhaps two or three years.

Rural Home Owners on Relief. A group of 40 farmer families in Tyrrell County or II per cent of the active relief load were found to own' property but not enough cleared acreage on which to be self-supporting as farmers. Nineteen are white and $2 x$ are colored. Although some own only a house and a garden plot, the typical family in this classification has a house and six acres of which three or four are in cultivation. Obviously this is insufficient to furnish a livelihood. Most of these families usually rent additional acreage each year. Much of the family income is derived from cash wages. The average income for 1933 was $\$ 108$, supplemented by relief payments of $\$ 68$, making a total per capita income of $\$ 28$.

Larger families are found in this group, making the problem of their rehabilitation even more difficult. Farming experience of these rural home owners is slightly poorer than that recorded for the small farm owners on relief. The average value 
of the property owned by these families is $\$ 376$. Forty-three per cent of the places are mortgaged for an average amount of \$215. Reports of mortgagees are more favorable for this group. In the matter of present possessions they fall far below the small farm owners. Opinions of landlords, case workers, and foremen concerning these families are uniformly better.

Again one reaches the conclusion that most of the families in this group are worthy and are capable of succeeding as farmers if economic difficulties of the present situation can be overcome. The need for loans to prevent mortgage foreclosures does not appear to be as pressing as was the case with the small farm owners on relief. However, the problem of enabling the families to become self-supporting as farmers is more difficult. All own a small place which to them is home. Moving the family to another locality is out of the question in most instances. Yet often a family is so situated that there is no available idle land for several miles around. Many of these families report that for the past few years they have been unable to rent as much land as they desired. This is attributed to the prostrate condition of fishing and lumbering in the region. Many formerly employed in these industries have been forced to return to the farm. Moreover the $g^{\circ}$ per cent of these families who depend in part upon cash wages in lumbering, fishing, or daily farm labor have met with little success along those lines for the past several years.

Tenants, Displaced Tenants and Day Laborers on Relief. A large percentage of the relief load in Eastern North Carolina is made up of tenants, former tenants, and day laborers. The tenant situation in the coastal trucking counties is not as serious as may be found in the region lying further inland. Therefore the make-up and present condition of this portion of the relief load in the far-Eastern section of the state is more favorable than would be found in the region where tenancy is an established and dominating institution.

Thirty-six per cent of the active relief cases in Tyrrell County own no real property, yet are capable of rural rehabilitation. This group is composed of 85 white and 50 colored families. Out of every ten cases in this group one is a cash renter, four or five are share croppers, three or four are displaced tenants, and one is a day laborer who has never had owner or tenant status. The family composition of these cases in most respects is like that of the two groups previously discussed. The younger average age of the head of the family in this group explains the fact that these tenants, displaced tenants, and day laborers possess an average farming experience of only I2 years as compared to I8 or I9 years for the other two classifications. An overwhelming majority of the families are experienced in raising most of the field crops, truck crops, and garden products common to the region. Experience in caring for livestock is less for these families.

The 74 tenant families with crops this year are cultivating an average of approximately 25 acres each. Four out of every five of the share cropper group are farming on halves, the landlord furnishing everything, while one in five is using his own 
team and gets two-thirds of the crop. Most of the displaced tenants and day laborers are farming a small acreage under farm contracts with the local relief administration. This phase of FERA's rural rehabilitation program will be given attention in a later section.

The average total income for this group last year, $\$ 129$ earned and $\$ 65$ relief payments, was much less than that for the small farm owners on relief but is more than the figure for the rural home owners. It is in the matter of present possessions that these families rate much lower than those in either of the other two groups. A very small number of automobiles, cows, mules, pigs, and chickens per one hundred families were recorded for this group. Almost all owe debts, the average being $\$ 80$ per family. Information obtained concerning the conduct of these families reveals little difference among the three groups. Opinions of landlords, case workers, and foremen are not quite as favorable as for farm and home owners.

The problem of rehabilitating tenants, displaced tenants, and day laborers on relief bristles with difficulties. Most of the day laborers probably are not competent to manage a crop of their own. Otherwise they would not be found on this lowest rung of the agricultural ladder. As for the average tenant, nothing more than bare subsistence even in good times is in prospect for him as long as he remains a part of the vicious system. What he needs is a boost upward to enable him to own his own place. On many large farms run by corporations or large land owners situations exist which are little short of peonage. This is true of some 15 of the relief cases investigated in Tyrrell County. Most of the tenant class are doubtless incapable of becoming owners, but some would certainly succeed. Only through government action can such an opportunity be afforded worthy tenants.

The problem of the displaced tenant farm family is perhaps the most serious of all. A parallel research project carried on in three counties in the center of the tobacco and cotton region of the state reveals that, where the tenancy rate is high, tenant displacements have been frequent. Furthermore, evidence indicates that the acreage reduction program is aggravating the problem. A detailed study of 825 displaced tenant farm families on relief rolls gives assurance that, although less capable on the whole and in a much poorer economic situation than the families discussed above, a majority would succeed in a rural rehabilitation plan. The problem of permanently rehabilitating 6,000 or 7,000 displaced tenant farm families in Eastern North Carolina is a nice one to test our ability in social and agricultural planning. With acreage being reduced, reabsorption into the existing economy of the region seems impossible. Not as much daily farm labor-almost the only source of income of the displaced tenant farm family in some sections-will be required to cultivate and harvest the reduced crop. The families have little experience in anything other than farming. Land and credit must be made available if these families are to be self-supporting. Rising prices for farm products do not help the farmer who does not have a crop to tend. 


\section{FERA Looks Toward Rural Rehabilitation}

Such then is the nature of the problem with which FERA is faced in Eastern North Carolina and in many parts of the South. Its rural rehabilitation program is making a start toward alleviating the distressing situation of these various groups of farmer families on relief. The matter of loans to prevent mortgage foreclosures is being handled by other governmental agencies. However, a debt conciliation committee, working toward this same end, is functioning in conjunction with ERA. Furthermore, it is furnishing capital and credit so that farmer families on relief rolls may be self-supporting this year. All relief cases capable of farming must sign contracts to farm a certain acreage as the local ERA farm supervisor dictates. Farmer families who do not sign such contracts are cut off relief rolls. Families under farm contract are furnished food until garden vegetables are in season, as well as seed and fertilizer for the contract acreage. All of this aid is to be repaid the relief administration in part of the crop or in labor on work projects. The amount of land under these ERA farm contracts in Eastern North Carolina ranges from 3 to 25 acres per family, probably averaging around eight or ten acres. Terms with landlords vary with the customs of various localities. Usually the landlord receives onehalf the crop if his team and equipment are being used and one-third if the tenant uses his own team. Many landlords have given the use of their idle land free of charge, or perhaps for certain improvements to the land. The use of vacant houses is given occasionally in return for repairs. In some cases ERA furnishes a mule for cultivating the crops of several relief families. One-fourth the feed crop usually goes for the care of the mule. The North Carolina ERA has purchased and distributed r,000 mules to be used by farmer families on relief throughout the state. In some parts of Eastern North Carolina idle land is extremely scarce. Where land is available, perhaps no relief families are nearby. Little has been done toward moving farmer families in town back to rural districts. Usually land is obtained near the town and is made available to urban relief families who sign ERA farm contracts.

This farm program of the relief administration has been received more cordially by relief clients and the general public alike than has been the case with any previous step. Its benefits are many. Owners who are unable to finance their farming operations are enabled at least to plant food and feed crops. Share croppets are assured of having some food and feed crops, rather than cultivating only a money crop as so many landlords desire. But it is the displaced tenant for whom the program is most beneficial. Many who were unable to get a crop for this year are now farming a small acreage in corn, field peas, potatoes, and a garden under the supervision of the relief administration.

In the main the results of this phase of the rural rehabilitation program are but temporary. Many relief families will be tided over this year, and a few will perhaps become self-supporting thereafter. However, there is another division of the program which seeks permanent rehabilitation of a large number of the most deserving 
and most capable relief families. One of the main objectives of the relief administration is rehabilitation where the family is now located. However, as has been pointed out, this is not always possible. Plans are under way to obtain large tracts of land in different sections of the state. Several counties owning land taken in for tax delinquencies have offered tracts to the state administration. In some instances land may be purchased. The best relief families will be settled on this land and furnished livestock, equipment and credit to give them a start. In a few years the families will begin repaying the relief administration on easy terms perhaps extending over twenty years, or refinancing may be undertaken by other agencies. Thus a family will have an opportunity of becoming a farm owner-the ambition of every tenant. The plan seeks to avoid the characteristics of colonization, but constant supervision will be necessary if success is to be achieved.

FERA's rural rehabilitation program is still in its infancy. Perhaps it will evolve into a long time plan for alleviating many intolerable situations now existent in our agricultural economy. Undesirable conditions have always been present in rural areas dominated by the tenant system. Depression and the unusually difficult problems encountered in efforts toward agricultural recovery have centered attention upon rural rehabilitation. First attempts of FERA along this line are encouraging. 


\section{.}

